\title{
FRONTEIRAS MÚLTILPLAS, IDENTIDADES PLURAIS - UM ENSAIO SOBRE MESTIÇAGEM E HIBRIDISMO CULTURAL
}

Vima Lia Martin

Universidade de São Paulo

$\mathrm{E}$

m 2002 a Editora SENAC de São Paulo publicou Fronteiras múltiplas, identidades plurais - um ensaio sobre mestiçagem e hibridismo cultural, do professor titular da Área de Estudos Comparados de Literaturas Comparadas de Língua Portuguesa, Benjamin Abdala Junior Com a liberdade de pensamento que tem caracterizado sua produção intelectual - Livre pensar, aliás, é o título da coleção em que se insere o volume - o autor discute a mescla cultural que, em tempos de globalização neoliberal, tem servido tanto para justificar arbitrariedades e autoritarismos como para enriquecer debates e delinear novos contornos identitários.

O livro, dividido em oito capítulos - Hibridismo e redes informacionais, Fronteiras múltiplas, Globalização, Estado, comunitarismo, Fronteiras: da imposição à cooperação, A cidade mais levantada do mundo, Fundações da polis brasileira, Dona Flor, um produto de exportação e Um sonho possível - caracteriza-se pela agilidade das reflexões desenvolvidas por Benjamin Abdala. Ao transitar por questões pertinentes a espaços geográficos e sóciopolíticos tão distintos como, por exemplo, o de Timor Leste e o dos Estados Unidos, e dialogar com o pensamento de Manuel Castells, Serge Gruzinski, Nestor García Canclini, Edward Said e Antonio Candido, entre outros, Benjamin Abdala não perde nunca de perspectiva o seu papel de intelectual brasileiro. Sabe muito bem onde tem os pés fincados, e seus vôos sempre ousados jamais traem sua vocação para esclarecer os sentidos das ideologias que regem a circulação de bens culturais - os fluxos comunicacionais assimétricos legitimadores da hegemonia. 
Logo no início da obra, o autor propõe o estabelecimento de múltiplas conexões entre culturas e áreas do conhecimento antes marcadas por fronteiras rígidas. Enfatizando que os antigos recortes já não respondem convenientemente às novas necessidades do capitalismo informacional, que revolucionou os meios de comunicação e vem transformando o mundo "num grande e virtual shopping center”, propõe uma pergunta bastante objetiva: como fazer frente a essa padronização da cultura? Sua resposta aponta para um caminho possível: é necessário efetivar aproximações de ordem comunitária. Nesse sentido, as articulações supranacionais entre setores politicamente não-hegemônicos são verdadeiras estratégias de resistência cultural e social, podendo atuar como fronteiras múltiplas de cooperação e desarticular os modelos de dominação que implicam competitividade e exclusão.

Se a globalização econômica opera num sentido bastante preciso, basicamente do norte para o sul, a circulação de produtos culturais e de discursos críticos pode e deve modificar a direção desse vetor tão implacável. É a partir desse pressuposto que Benjamin Abdala constrói o seu pensamento. No âmbito das literaturas de língua oficial portuguesa - sempre apreendidas em seu sentido político-cultural - seu olhar flagra as marcas do multiidentitarismo que afirma nossa mestiçagem cultural. E ele alerta: se a incorporação do alheio faz parte de culturas mestiças, abertas, como a brasileira, para que a importação seja produtiva ela não deve se dar acriticamente, mas constituir matéria incorporada que propicie a dinamização ou ativação de nossas experiências internas.

Lembremos que o autor, em outra ocasião, já propusera a prática do "comparatismo da solidariedade", exercício crítico que valoriza a circulação dos repertórios culturais no interior do macrossistema das literaturas de língua oficial portuguesa, tendo em vista a integração ibero-afro-americana. Ora, esse descentramento de óptica, que subverte a direção tradicionalista dos estudos comparados de matriz européia, solicita uma teoria literária descolonizada, capaz ponderar as tensões entre localismo e cosmopolitismo e de operar com critérios próprios de valor.

Desse modo, no espaço múltiplo e plural das literaturas de língua portuguesa, a valorização de textos de Vinícius de Morais - que retoma e amplia o repertório lírico camoniano -, Eça de Queirós, Jorge Amado, Graciliano Ramos, Francisco José Tenreiro, José Saramago, só para citar alguns, tem 
como foco prioritário a problematização da identidade. A experiência da incorporação de matérias heterogêneas e muitas vezes contraditórias é marca constitutiva das identidades nacionais forjadas no - e pelo - tecido literário e opõe-se à homogeneização centralista alardeada pelas esferas oficiais.

Em capítulos específicos, que permitem um maior aprofundamento das análises literárias, o caráter mestiço e híbrido de nossa cultura é ilustrado através da leitura de textos criteriosamente escolhidos. Assim, a perplexidade de Guimarães Rosa diante do projeto urbanístico que conduziu a construção de Brasília - o oásis simbólico da modernidade brasileira - é descortinada na fatura de contos como "As margens da alegria" e "Os cimos" (ambos de Primeiras estórias), em que a personagem central - o Menino apresenta uma percepção ambígua do novo espaço que pretendia instaurar, a despeito de toda a diversidade que nos constitui, uma "ilha de civilização" no planalto central brasileiro.

Em seguida, o estudo da adaptação cinematográfica do romance de Jorge Amado Dona Flor e seus dois maridos serve como paradigma para a discussão das interações entre literatura e cinema e, por extensão, da mídia audiovisual no Brasil e na América Latina. O autor enfatiza o fato de que o filme de Bruno Barreto, de 1976, transforma a imagem da protagonista num produto de exportação que veicula a sensualidade tropicalizada da mulher brasileira, anulando as contradições e as violações que caracterizam seu comportamento na narrativa literária. Mas também considera a densidade e o alcance da canção-tema do filme, de autoria de Chico Buarque, - O que será (À flor da pele) - que perfaz não apenas uma crítica de costumes como também opera uma denúncia da situação de sufoco político então vivido no país através da referência a outro momento histórico - a ditadura de Getúlio Vargas. O discurso crítico se insinua, desse modo, nas brechas de um produto estereotipado, nas franjas daquilo que a mestiçagem pode nos oferecer como possibilidade transgressora.

Na parte final do livro, "Um sonho possível" se anuncia. A utopia de Benjamin Abdala que, por sua relação direta com a práxis, aproxima-se da utopia concreta proposta pelo filósofo alemão Ernst Bloch, reitera a face solidária do hibridismo cultural. Não para copiar passados que não retornarão, mas para afiançar projetos possíveis, que promovam uma efetiva democratização das esferas política, econômica, social e cultural. A di- 
mensão ética da obra se desvela aqui com grande clareza. Reflexão e ação, teoria e prática caminham juntas na aposta de que o hibridismo cultural, desde que não reduzido a um pastiche sem história, pode favorecer o entendimento entre pessoas e povos.

O esgarçamento da cidadania e a explosão da violência, principalmente nos países mais pobres, talvez sejam as mais terríveis conseqüências da globalização econômica. Diante delas, parece-nos imperativo - ainda e mais uma vez - ressaltar as tensões entre centro e periferia e escancarar as estratégias de alienação política. Nesse sentido, a palavra empenhada de Benjamin Abdala Junior não deixa espaço para titubeações. Suas convicções são firmes e, sabemos nós, têm propiciado travessias bastante significativas num mundo cada vez mais carentes de utopias libertárias. 